\title{
El grupo Che Sudaka en tránsito por Austria: una entrevista
}

\author{
Mario SOTO DELGADO (Innsbruck)
}

Che Sudaka es un cuarteto formado por los dos hermanos argentinos, Leo y Kachafaz, y sus dos compañeros colombianos, Jota y Cheko, y que nació en España en 2002. Sus componentes habían llegado como emigrantes ilegales allá por el año 2000 y empezaron como músicos callejeros a buscarse un espacio en la escena musical alternativa. Hoy, con más de 15 años de vida, más de mil conciertos han alcanzado renombre mundial.

En sintonía con el estilo de Manu Chao, y con su ayuda, iniciaron su revolución particular luchando contra la xenofobia y el racismo y desde entonces vienen transmitiendo a sus fans alegría de vivir, combinada con la más pura actitud crítica. El grupo ofrece una interesante fusión de estilos y se destaca por su impronta claramente latina. El mensaje antisistema, pero nada derrotista, de estas "almas rebeldes" (como se llama también su último álbum) es un activismo con tono de reivindicación que sienta muy bien en estos tiempos en que vivimos.

$\mathrm{Al}$ escuchar sus temas apreciamos frescura y fuerza; pero donde realmente se aprecia su torbellino de energía es en el directo, como bien tuvimos ocasión de comprobar en el concierto que dieron el 10 de febrero 2018 en Innsbruck, en el Treibhaus. Esta institución local lucha desde hace años por traer lo mejor de la música internacional a esta pequeña ciudad. Y, para la música española, en febrero de 2018 ha sido en doble formato: primero pasó por el escenario del Treibhaus la conocida Amparanoia y, una semana después, Che Sudaka, a quien entrevistamos en esta ocasión.

Os pido que le contéis a nuestros lectores algo sobre vuestros orígenes y cómo se creó el grupo Che Sudaka. ¿Es cierto que el grupo ya existía bajo el nombre de Correcaminos?

Correcaminos era el nombre del grupo donde tocaba yo mismo (Leo) en Argentina desde el 1993 y con el cual nos vinimos a Barcelona en 2001. A las dos semanas de llegar el grupo se disolvió. Pasó un año de ese suceso y ahí recién nació Che Sudaka. No es el mismo grupo, aunque algunas de las canciones del primer álbum Trippi Town venían de aquella época.

Después de hacer música en Latinoamérica acabasteis yéndoos a España y os afincasteis en Barcelona. Supongo que conocéis muy bien los dos lados. ¿̇A nivel musical qué diferencias habéis notado, qué funciona de otra manera allá y acá? ¿Cuál es vuestra casa? 
Nuestra única casa siempre es el presente. Si no, viviríamos extrañando siempre algo. Vivimos en Barcelona desde hace 17 años, donde tenemos nuestras familias 'nuevas', pero la familia vieja está en Argentina y en Colombia. Y a la vez estamos de gira casi permanente, fuera de España, así que como no apreciemos el aquí y ahora, no lograremos ser felices jamás. Las diferencias entre los dos mundos son más notorias en Francia o en Alemania. En España la manera de hacer se parece más a Latinoamérica.

Háblame de vuestros orígenes musicales. ¿Qué otros gustos o influencias musicales tenéis?

Nuestros gustos musicales son variados, pero si en algo estamos de acuerdo es en que nos gusta la música con alma. Pero escuchamos de todo. Venimos del rock, del ska, del reggae, del new metal, pero cada vez nos estamos poniendo más folklóricos. Mucha cumbia y música latinoamericana. Ahí están nuestras raíces.

¿De dónde viene ese enfoque crítico y social que se nota en vuestros temas? ¿Quién elabora las letras?

Desde los principios, expresamos siempre nuestro punto de vista. Pero también tuvimos en cuenta que, ante cualquier cosa que se manifieste, hay que aportar soluciones. Si no, no tiene sentido abrir la boca. Las letras las escribimos Leo, Kachafaz, y en los últimos tiempos se sumó Sergio con "Cuando será" y "Plegaria”. Eso ayuda a comunicar más sentimientos y a trabajar otros registros musicales.

Atrae mucho esa mezcla que se aprecia en vuestros temas. ¿Cómo se montan los números? ¿Es un resultado grupal o más individual?

Somos un grupo homogéneo de cuatro músicos que forman el ente Che Sudaka. Pero igualmente, al ser una banda independiente tenemos que interpretar varias funciones dentro del equipo. Intentamos hacer todo entre todos. Después de 15 años juntos ya cada uno sabe cuál es su lugar. Obviamente cada uno es más fuerte en un cierto campo. Creo que nos complementamos bien los cuatro músicos y Rogue, nuestro manager. Somos una familia en toda regla donde cada uno aporta lo que sabe, así que vamos directos al grano, y el resultado nos llena el alma.

Después de casi 16 años de camino con vuestra banda en los que habéis dado conciertos por todo el mundo, ¿qué le queda por hacer a Che Sudaka?

Solo nos queda seguir viviendo. Elegimos crecer juntos y en familia. Ese es el plan. Seguir juntos hasta que nos toque partir. Ojalá sea, y siempre, con la música de testigo. 
¿Cuál es el mensaje que queréis transmitir con vuestra música? ¿Cuál es el poder que le veis a la música?

La música nos salvó la vida. Nos ayudó a conectar con seres de todo el planeta. Creemos que la música es la magia que lo une todo. Por eso tocamos. Para unirnos con el entorno, en paz y con alegría y felicidad.

Y para terminar, me gustaría que hicierais una reflexión sobre la evolución musical que habéis tenido como banda. ¿Qué metas os quedan por cumplir?

Nuestra evolución siempre fue orgánica. Comenzamos soñando en nuestras bandas de rock en Sudamérica en los '90 (Correcaminos y Sinaca). Luego vinimos soñando con vivir haciendo música por todo el planeta y lo conseguimos. Ahora llegó el momento de perpetuarnos en el oficio. Siempre disfrutando del estar juntos y tocando la música que nos llega al alma. Primero, a nosotros; y, por añadidura, a la gente. Es maravilloso lo que nos toca vivir. Intentaremos contagiar nuestra alegría allá por donde vayamos. Esa es la misión. Allá vamos... y decimos: "Arriba la vaina hasta ke choke China kon Afrika!”

¡Gracias! 